\title{
Analisis Rekayasa Sub Sistem Penujang Di Salah Satu Sentra Pertanaman Kakao, Kecamatan Kumpeh Ilir, Kabupaten Muaro Jambi
}

\author{
Suharyon \\ Balai Pengkajian Teknologi Pertanian (BPTP) Jambi, Indonesia \\ Email: suharyonhariyon@gmail.com
}

\begin{abstract}
ABSTRAK
Dalam upaya mengembangkan sistem usahatani dan kelembagaan tanaman kakao di suatu wilayah diperlukan pendekatan hubungan antara kelompok tani dengan kelembagaan lain yang mendukung. Dengan terjalinnya kerja sama kelembagaan yang baik, masalah yang dihadapi petani bisa diserahkan sekaligus diharapkan terjadi difusi teknologi melalui lembaga atau institusi terkait di daerah. Dengan memberdayakan kelembagaan yang mendukung adopsi teknologi yang diberikan kepada kelompok tani FSA (Farming System Analysis) dalam bentuk kerja sama akan membantu memecahkan masalah-masalah yang dihadapi petani. Berdasarkan pemikiran tersebut, maka perlu dilakukan kajian analisis rekayasa kelembagaan penunjang teknologi usahatani tanaman kakao. Kegiatan ini dilaksanakan di desa Betung, Kecamatan Kumpeh Ilir Kabupaten Muaro Jambi, dengan tujuan menemukan perlakuan/intervensi yang efektif dan meningkatkan pemberdayaan, serta kerja sama kelembagaan guna menjamin adopsi teknologi sistem usahatani tanaman kakao yang berkelanjutan. Pendekatan yang digunakan adalah SWOT ANALYSIS yaitu identifikasi kekuatan, kelemahan, peluang, dan ancaman. Metodologi yang digunakan dalam kegiatan ini dengan menerapkan metode Participatory Research Appraisal (PRA), untuk menggali masalah yang dihadapi oleh petani tanaman kakao. Alternatif intervensi yaitu dibentuknya beberapa kelompok tani atau dapat disebut Gapoktan yang diberi nama Usaha Bersama, diskusi singkat tentang sistem usahatani tanaman kakao, melihat kebutuhan mendesak kelompok tani, dan menghubungkannya dengan lembaga pendukung. Bedasarkan hasil PRA maka permasalahan yang diperioritaskan adalah (1) Bibit kakao yang berkualitas yang masih kurang sampai kepetani, (2), modal, () pupuk bersubsidi, (4) pertemuan antara kelompok. dan (5) bimbingan teknis untuk tanaman kakao. Tujuan menemukan perlakuan/intervensi yang efektif dan meningkatkan pemberdayaan, serta kerja sama kelembagaan guna menjamin adopsi teknologi sistem usahatani tanaman kakao yang berkelanjutan.
\end{abstract}

Kata Kunci: Sub sistem penunjang, tanaman kakao. 


\section{PENDAHULUAN}

Kabupaten Muaro Jambi khususnya Provinsi Jambi merupakan salah satu daerah penghasil tanaman kakao. Luas areal perkebunan kakao di Provinsi Jambi dari tahun 2011 sampai tahun 2015 terus mengalami peningkatan. Tercatat pada tahun 2011 luas areal perkebunan kakao adalah 1.986 Ha dan sampai ditahun 2015 telah mencapai 2.270 Ha. Peningkatan jumlah areal tanaman kakao tidak lain dikarenakan semakin tingginya minat petani terhadap budidaya kakao. Budidaya kakao dirasa memberikan keuntungan untuk rumah tangga petani sehingga pemanfaatan lahan kosong ditingkatkan dengan melaksanakan budidaya kakao (Dinas Perkebunan Provinsi Jambi, 2015).

Suatu komunitas dapat dilihat sebagai sebuah komponen sistem sosial, dimana komponen-komponennya saling berhubungan secara fungsional. Antar kelompok tani dalam hamparan di lokasi FSA (Farming System Analysis) juga memiliki keterkaitan kelompok. Di samping itu, juga terdapat hubungan eksternal atau hubungan antara unsur-unsur internal dan eksternal. Dalam upaya pengembangan sistem penunjang usahatani tanamn jeruk di suatu wilayah, diperlukan pendekatan hubungan antara kelompok dengan kelembagaan lain yang mendukung (Anonim, 2011).

Berdasarkan hasil penelitian sebelumnya kelembagaan yang diberdayakan adalah kelompok tani "Usaha Bersama" Desa Betung, Kecamatan Kumpeh Ilir Kabupaten Muaro Jambi". Dari hasil survei diperoleh informasi bahwa ada beberapa faktor yang mempengauhi terhadap produktivitas tanaman kakao seperti : (1) tingkat penghasilan, tenaga kerja bertujuan mendapatkan penghasilan menghidupi dirinya beserta keluarganya secara layak, (2) jaminan sosial yang merupakan sesuatu yang dapat menambah pendapatan, (3) motivasi tenaga kerja perlu didorong untuk dapat lebih bergairah dalam melaksanakan pekerjaan sehingga menyebabkan penurunan produktivitas. Selain permasalahan tersebut diatas juga dipengaruhi oleh cuaca atau iklim, pada usahatani tanaman kakao sebagian besar masih menggunakan bibit lokal, masih belum terjadwal pertemuan dengan anggota kelompok sehingga jadwal pelaksanaan kegiatan kurang serentak dan dapat menyebabkan peningkatan produksi dan produktivitas tanaman kakao, disamping kurang bersahabatnya cuaca pada saat petani melakukan aktifitas sehari-harinya (merawat tanamannya, dan pengendalian atau penyemprotan hama tanaman dan sebagainya) (hasil wawancara dengan ketua kelompok tani dan petugas lapang (PPL).

Masyarakat Desa Betung, Kecamatan Kumpeh Ilir, Kabupaten Muaro Jambi pada umumnya bermata pencaharian sebagai petani baik petani kebun maupun padi dan tanaman palawija lainnya. Masih ada ditemukan permasalahan yang dihadapi petani membutuhkan peningkatan penanganan dan pembinaan agar usahatani tananaman kakao yang dilakukan menjadi lebih baik. Dalam hal ini, peneliti Balai Pengkajian Teknologi Pertanian (BPTP) Jambi berinisiatif melakukan 
upaya perbaikan melalui pengamatan pada kelompok tani tanaman kakao saja dan penelusuran terhadap institusi sebagai pendukung proses adopsi teknologi dan pengembangan wilayah. Dengan terjalinnya kerja sama kelembagaan yang mantap, masalah yang dihadapi petani terutama petani kakao dapat diatasi sekaligus diharapkan terjadi proses difusi teknologi melalui lembaga tersebut. Dengan internalisasi teknologi petani, maka proses adopsi teknologi diharapkan bisa lebih cepat. Dengan memberdayakan kelembagaan yang mendukung adopsi teknologi kepada kelompok tani FSA khususnya dalam bentuk kerjasama, akan membantu memecahkan masalah-masalah yang dihadapi petani. Dengan demikian, tujuan pengkajian adalah menemukan intervensi efektif dan meningkatkan pemberdayaan, serta kerja sama kelembagaan guna menjamin adopsi teknologi sistem usahatani tanaman kakao yang berkelanjutan melalui identifikasi kekuatan, kelemahan, peluang, dan ancaman dengan pendekatan SWOT (Strenghs, Weaknesses, Opportunities, Threats) analisis. Tujuan menemukan perlakuan/intervensi yang efektif dan meningkatkan pemberdayaan, serta kerja sama kelembagaan guna menjamin adopsi teknologi sistem usahatani tanaman kakao yang berkelanjutan (Anonim, 2012).

\section{METODOLOGI PENGKAJIAN}

\section{Pengertian dan Tahapan Kegiatan}

Kelembagaan yang dimaksud dalam pengkajian mencakup kelembagaan aparat desa, kelompok tani, lembaga adat, dan instansi pemerintah. Sedangkan institusi meliputi norma-norma dan perilaku petani yang berlaku di wilayah setempat, misalnya aturan-aturan yang mengatur antara patron dan klien. Sesuai dengan tujuan pengkajian akan dilakukan tahapan-tahapan sebagai berikut (1) menerapkan metoda Participatory Research Appraisal (PRA) untuk menggali masalah yang dihadapi oleh petani, (2) setelah masalah disusun berdasarkan prioritas, maka dilakukan ujicoba bersama di petani sesuai dengan kemampuan petani, (3) mempelajari kebijakan yang dioperasionalkan oleh lembaga terkait, dan (4) menghubungi lembaga-lembaga terkait untuk mengemukakan masalah yang dihadapi petani.

\section{Kebutuhan Teknologi Petani}

Berdasarkan identifikasi, kebutuhan teknologi petani meliputi (1) Bibit kakao yang berkualitas masih kurang sampai kepetani, (2), modal, (3) pupuk bersubsidi, (4) pertemuan antara kelompok. dan (5) bimbingan teknis untuk tanaman kakao secara rutin. Peubah yang diamati adalah (1) masalah dan tantangan kelompok tani, (2) alternatif pemecahan masalah oleh kelompok tani, (3) frekuensi dan topik pertemuan antara kelompok tani dengan lembaga terkait, (4) bentuk kerja sama dengan lembaga terkait, (5) program aksi yang diterima dan ditolak, serta (6) keberhasilan program aksi. 


\section{Diagram Kelembagaan (Venn).}

Diagram kelembagaan menunjukkan pandangan anggota masyarakat tentang lembaga dan organisasi lokal termasuk bagaimana hubungan masing-masing kelembagaan dan organisasi itu mempengaruhi kehidupan masyarakat di pedesaan. Diagram ditunjukkan dengan ukuran lingkaran berbeda-beda yang menunjukkan pentingnya suatu kelembagaan di pedesaan. Keterkaitan antar lembaga ditunjukkan dengan ada tidaknya kontak atau kerja sama dalam pengambilan keputusan atau adanya keanggotaan ganda. Lingkaran bersentuhan menunjukkan ada hubungan atau informasi tersampaikan antara lembaga/organisasi, sedangkan bila terdapat tumpang tindih berarti ada kerja sama dan keterkaitan atau keanggotaan ganda dalam pengambilan keputusan (Shawki,B.C. 1999, Jhon Dixon.A.G. 2001 dan Umarjono, 1992).

\section{HASIL DAN PEMBAHASAN}

\section{Karakteristik Wilayah Kabupaten Muaro Jambi Letak Geografis.}

Kabupaten Muaro Jambi merupakan salah satu kabupaten di Provinsi Jambi yang dibentuk berdasarkan Undang-undang Nomor 54 Tahun 1999 sebagai daerah pemekaran dari Kabupaten Batang Hari, secara resmi pemerintahan Kabupaten Muaro Jambi mulai dilaksanakan pada tanggal 12 Oktober 1999. Pusat Pemerintahan di Kota Sengeti sebagai Ibukota Kabupaten Muaro Jambi dengan Pusat Perkantoran di Bukit Cinto Kenang Kecamatan Sekernan. Kabupaten Muaro Jambi memiliki letak geografis yang strategis, berada di hinterland Kota Jambi. Hal ini memberikan keuntungan bagi Kabupaten Muaro Jambi karena kabupaten ini memiliki peluang yang cukup besar sebagai daerah pemasok kebutuhan Kota Jambi, seperti pemasaran hasil pertanian, perikanan, industri dan jasa. Secara geografis, Kabupaten Muaro Jambi terletak antara 1051' - 2001' Lintang Selatan dan diantara 103015' - 104030' Bujur Timur dengan luas wilayah 5.264 Km2 dan batasan wilayah sebagai berikut:

1. Sebelah Utara : Kabupaten Tanjung Jabung Timur

2. Sebelah Timur: Kabupaten Tanjung Jabung Timur

3. Sebelah Selatan : Provinsi Sumatera Selatan

4. Sebelah Barat: Kabupaten Batang Hari dan Kabupaten Tanjung Jabung Barat Secara administratif Kabupaten Muaro Jambi terdiri dari 11 (sebelas) kecamatan, 150 desa dan 5 kelurahan. Nama-nama kecamatan dan ibukota kecamatan dalam Kabupaten Muaro Jambi antara lain:

1. Kecamatan Mestong dengan Ibukota Sebapo

2. Kecamatan Sungai Bahar dengan Ibukota Marga

3. Kecamatan Bahar Selatan dengan Ibukota Tanjung Mulya

4. Kecamatan Bahar Utara dengan Ibukota Talang Bukit 
5. Kecamatan Kumpeh Ulu dengan Ibukota Pudak

6. Kecamatan Sungai Gelam dengan Ibukota Sungai Gelam

7. Kecamatan Kumpeh dengan Ibukota Tanjung

8. Kecamatan Maro Sebo dengan Ibukota Jambi Kecil

9. Kecamatan Taman Rajo dengan Ibukota Kemingking Dalam

10. Kecamatan Jambi Luar Kota dengan Ibukota Pijoan

11. Kecamatan Sekernan dengan Ibukota Sengeti

Kabupaten Muaro Jambi merupakan wilayah dengan permukaan tanah yang didominasi oleh permukaan yang relative datar. Hal ini dibuktikan dengan data yang disajikan dalam Muaro Jambi Dalam Angka Tahun 2014, bahwasanya wilayah Kabupaten Muaro Jambi dengan ketinggian permukaan tanah antara 0 35 mdpl. Untuk lebih jelasnya mengenai tinggi permukaan tanah wilayah Kabupaten Muaro Jambi diatas permukaan laut dijelaskan di tabel dan peta berikut:

Gambar 1. Peta Administrasi Kabupaten Muaro Jambi

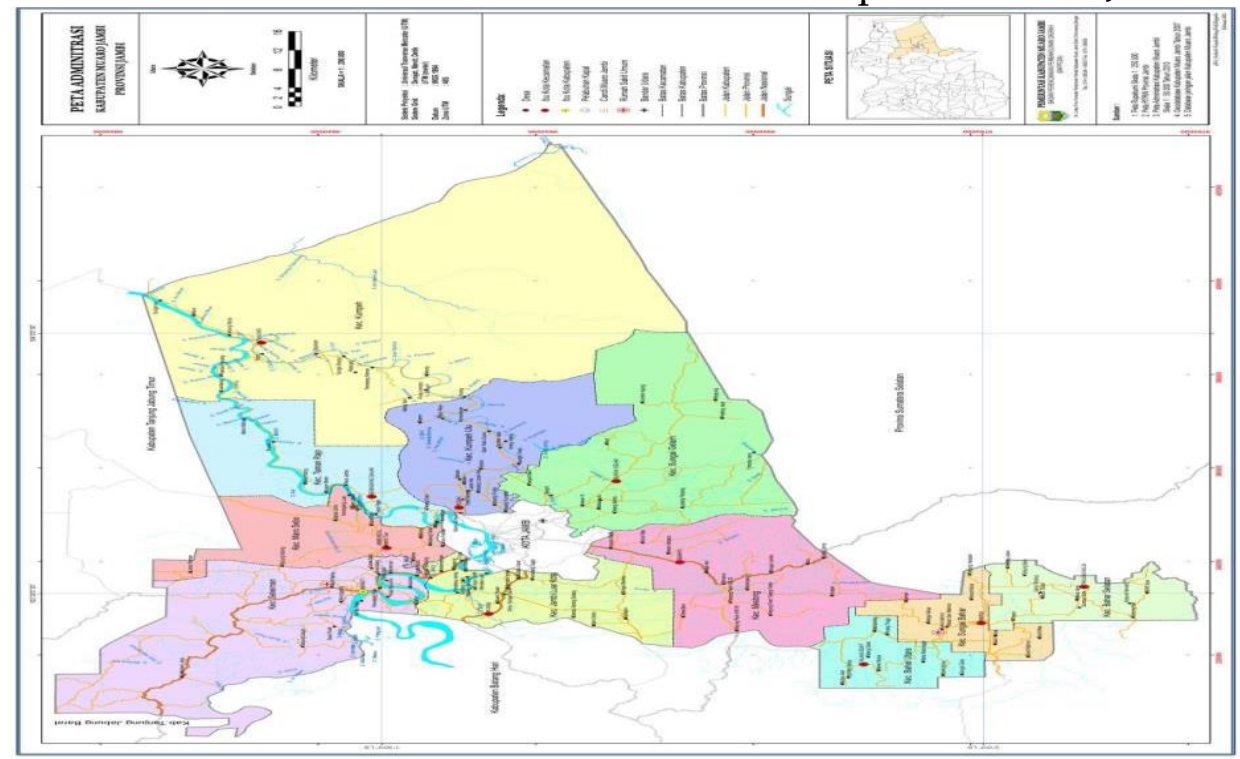

\section{Kondisi Sosial dan Ekonomi}

Capaian kemajuan pendidikan di Kabupaten Muaro Jambi pada Tahun 2012 telah menunjukkan hasil yang cukup menggembirakan. Hal ini ditunjukkan oleh tingkat kelulusan SD, SMP hingga SMA/SMK yang mencapai 100\%. Disamping itu peningkatan perkembangan pendidikan juga terlihat dengan semakin berkembangnya minat belajar anak usia sekolah di berbagai jenis bidang studi dan jenjang pendidikan. Selain itu, pelaksanaan program pendidikan juga telah menunjukkan perkembangan yang meningkat dengan adanya penyediaan pelayanan pendidikan yang semakin luas dan menjangkau daerah terpencil, daerah dengan penduduk yang relatif sedikit dan daerah yang rentang kendalinya lebar dengan dibangunnya sekolah di daerah tersebut. Pembangunan di setiap jenjang. 


\section{Profil Kelembagaan di Lokasi Pengkajian}

Kelompok tani sebagai kelembagaan petani di pedesaan pada dasarnya berfungsi sebagai wadah kerja sama, kelas belajar, sedangkan yang terkait dengan pengelolaan unit produksi belum berfungsi sebagaimana mestinya. Kelompok tani/Poktan Usaha Bersma di desa Betung, Kecamatan Kumpeh Ilir kemampuannya bervariasi meliputi kelas pemula, kelas madya, dan kelas lanjut. Kelompok tani yang telah terbentuk ini aktivitasnya masih kurang, karena frekuensi musyawarah/pertemuan kelompok tani masih rendah.

Koperasi unit desa (KUD) sekarang berubah menjadi Gabungan kelompok tani (Gapoktan) sesuai fungsinya sebagai pelayan masyarakat petani dalam penyediaan saprodi dan tempat simpan pinjam sangat pengaruh terhadap masyarakat berada dalam lingkaran desa. Keberadaan yang ada adalah Lembaga Pemberdayaan Masyarakat (LPM) yang berfungsi sebagai tempat diskusi kelompok dan tidak sama fungsinya seperti KUD. Dengan demikian, LPM ini seharusnya dapat dimanfaatkan untuk melayani kebutuhan masyarakat/petani sebagai wadah pembantu perekonomian di pedesaan. Adanya kios-kios saprodi yang menyediakan sarana produksi juga dirasakan masyarakat/petani sebagai suatu untuk mendapatkan bibit bermutu dan pupuk. Kendala yang dihadapi petani adalah pengaruh cuaca atau iklim sehingga berpengaruh untuk pertumbuhan usahatani tanaman kakao mereka, kekurangan modal untuk membeli kebutuhan sehari-harinya, dan kondisi seperti ini merupakan kendala dalam mengatasi permodalan petani terutama fasilitas kredit usahatani. Kelembagaan pendidikan yang tersedia di Desa Betung Kecamatan Kumpeh Ilir Kabupaten Muaro Jambi yang dirasakan sangat besar peranannya, seperti: Sekolah taman kanak-kanak (TK) 1 buah, Sekolah Dasar (SD) 1 buah, mesjid 2 buah, Madrasah 1 buah, musholla 1 buah, pesantren 1 buah, dan pasar masarakat. Tersedianya mesjid dan musholla sebanyak 1 buah tersebut sangat besar peranannya menjalankan bagi umat muslim sebagai sarana dalam menjalankan peribadatannya.

\section{Rekayasa Kelembagaan}

Rekayasa kelembagaan adalah upaya yang harus dilakukan dalam rangka membentuk suatu organisasi yang sesuai dengan kebutuhan petani dalam melaksanakan sistem usahataninya. Hal yang penting adalah memfungsikan organisasi tersebut, sehingga keberadaan dan manfaatnya dapat dirasakan oleh setiap anggota petani sesuai dengan tujuan dan harapan anggotanya. Dengan demikian, rekayasa kelembagaan adalah membangun aspek fisik dan non fisik dari kelembagaan penunjang pembangunan pertanian di pedesaan. Keterkaitan antar kelembagaan di Desa Betung, Kecamatan Kumpeh Ilir digambarkan pada diagram Venn berikut (Gambar 1). 


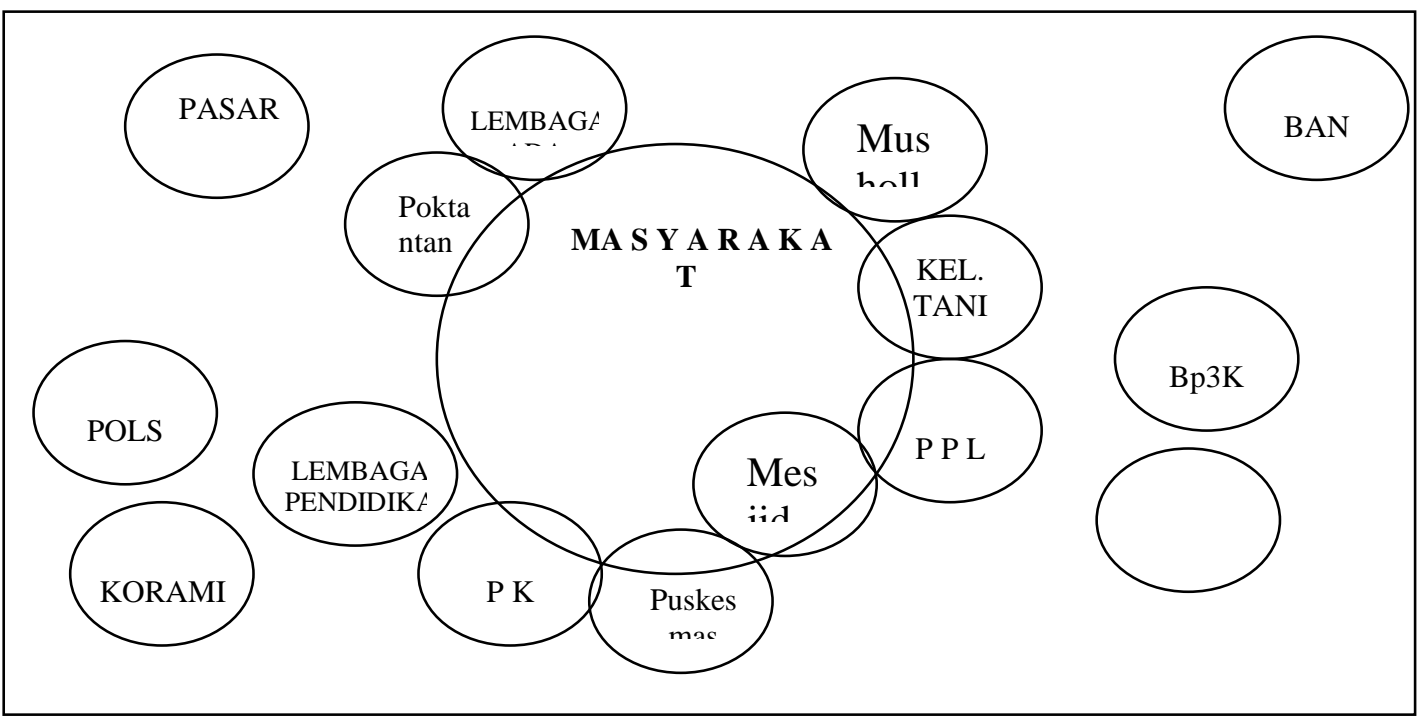

\section{Masalah dan Strategi Pemecahan}

Dari hasil Partisipatori Rural Appraisal (PRA) yang dilakukan, diidentifikasi berbagai masalah yang dihadapi masyarakat setempat yang sangat mempengaruhi sumber pendapatannya. Sumber pendapatan dari masyarakat setempat adalah dari bertani, berkebun sawit, bertanam padi sawah, tanaman palawija, hortikultura, juga beternak ayam kampung lainnya. Dari hasil diskusi yang dilakukan dengan petani kakao diperoleh bahwa masih ada yang belum bertanam kakao padahal tanaman ini merupakan bagian penghasilan mereka selain tanaman tanaman pangan lainnya, artinya masih ada yang belum kompak dalam melakukan bertanam kakao secara serentak, kecuali ada bantuan bibit dari pemerintah setempat ditingkat petani, tanaman kakao yang ada sekarang adalah hasil penenlitian dari Balit kakao jember Jawa Timur yang dimulai sejak tahun 2000 dengan luasan lebih kurang 30 hektar, petani tidak memakai bibit unggul tanaman kakao dan tidak melakukan pembibitan baru. Disisi lain masih ditemukan: masih kurangnya kekompakan anggota kelompok, belum ada mendapat bantuan bibit unggul pada tahun belakang ini, kecuali bantuan dari Balit kakao Jdember tahun 2000 yang lalu, sehingga mempengaruhi terhadap produktivitas, dan juga mengenai pemasaran. permasalahan utama seperti yang dibahas sebelumnya yang dihadapi masyarakat/petani adalah ketersediaan air untuk lahan sawahnya waktu musim kemarau sulit mengairi sawahnya kecuali air hujan, saluran air tata air mikronya sudah banyak yang rusak sehingga tempat mengalirnya air kesawah terganggu dan dapat menurunkan produktivitas, serta kekurangan modal (Tabel 1). 
Tabel 1. Beberapa masalah pada usaha tani tanaman kakao di Desa Betung, Kecamatan Kumpeh Ilir Kabupaten Muaro Jambi

\begin{tabular}{|c|c|c|c|c|c|c|c|}
\hline \multirow{3}{*}{ No } & \multirow{3}{*}{ Masalah } & \multicolumn{4}{|c|}{ Kelompok } & \multirow{3}{*}{ Jumlah } & \multirow{3}{*}{ Prioritas } \\
\hline & & & U & 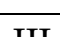 & TW & & \\
\hline & & $\frac{1}{2}$ & 11 & $\frac{111}{2}$ & $\frac{1}{2}$ & & \\
\hline 1 & Mendapatkan bibit berkualitas & 3 & 4 & 3 & 3 & 13 & I \\
\hline 2 & Modal & 2 & 3 & 3 & 2 & 10 & II \\
\hline 3 & Pupuk bersubsdidi & 2 & 2 & 3 & 3 & 10 & II \\
\hline 4 & Pertemuan kelompok kurang & 2 & 2 & 3 & 2 & 9 & III \\
\hline 5 & Bimbingan teknis & 2 & 2 & 1 & 2 & 7 & IV \\
\hline
\end{tabular}

Keterangan : I = sangat penting, II = penting, III = cukup penting, IV = agak penting, $\mathrm{V}=$ kurang

Dari lima permasalahan yang telah teridentifikasi, maka dapat diperioritaskan (1) mendapat bibit yang tidak berkualitas, (2) kekurangan modal, masih kurangnya mendapat pupuk bersubsidi, (3) masih kurangnya mendapatkan pupuk bersubsidi, (4) Pertemuan kelompok masih kurang, dan (5) bimbingan teknis masih lemah. Permasalahan yang ditemukan pada tanaman kakao tersebut adalah mendapatkan bibit yang berkualitas masih kurang, tingkat penerapan bimbingan teknologi lainya. Di samping itu, petani belum banyak melakukan sanitasi terhadap tanaman kakao yang sudah ada. Oleh karena, itu disarankan kepada lembaga-lembaga penelitian yang relevan agar melakukan introduksi teknologi yang bisa mengatasi masalah tersebut diatas.

Permasalahan sumber air terutama disawah-sawah mereka yang belum tertata yang banyak dijumpai pada usahataninya adalah perawatan yang kurang baik sehingga dapat mempengaruhi terhadap produksi, petani masih belum banyak timbul kesadaranya untuk merawat tanaman kakao yang sudah ada. Di samping itu, petani juga belum banyak melakukan diskusi-diskusi dengan petugas lapang sebagai pendamping yang hampir hadir setiap hari dilokasinya. Dengan kehadiran Instansi Badan Litbang Pertanian dalam hal ini Balai Pengkajian Teknologi Pertanian (BPTP) akan dapat membantu dari sisi teknologi, baik menyediakan bibit bermutu, dan teknologi inovasi pertanian secara keseluruhan. penyediaan Dari segi pemasaran juga perlu diperbaiki karena berdampak terhadap hasil, padahal hasil teknologi yang dilakukan harus didukung oleh keberadaan pasar yang memadai (Aima, 2002, Bambang Irawa et al, 2005).

\section{KESIMPULAN DAN IMPLIKASI KEBIJAKAN}

\section{Kesimpulan}

Berdasarkan hasil PRA maka terdapat permasalahan yang dihadapi petani Desa Betung, Kecamatan Kumpeh Ilir Kabupaten Muaro Jambi berdasarkan 
prioritasnya, berturut-turut adalah (1) mendapatkan bibit kakao yang berkualitas masih terbatas, (2) sentuhan modal dari pemerintah masih kurang, (3) mendapatkan pupuk bersubsidi masih sulit, (4) pertemuan kelompok masih kurang, dan (5) bimbingan teknis dari petugas masih kurang, faktor iklim yang bisa mempengaruhi terhadap produktivitas usahatani tanaman kakao. Inovasi kelembagaan sangat diperlukan untuk membenahi semua kelembagaan. Seluruh komponen yang terlibat dalam kegiatan usahatani tanaman kakao agar dapat berfungsi dengan baik. Kelompok tani Desa Betung, Kecamatan Kumpeh Ilir, Kabupaten Muaro Jambi dalam pelaksanaan inovasi Farming System Analysis (FSA) sangat responsif terlihat dari pertemuan dan wawancara langsung yang dilaksanakan selama kegiatan PRA baik secara kelompok maupun individu. Keputusan petani menjalankan usahatani tanaman kakao dapat dilakukan secara integritas baik petani itu sendiri maupun instansi terkait.

\section{Implikasi Kebijakan}

1. Usahatani kakao di Desa Betung, Kecamatan Kumpeh Ilir, Kabupaten Muaro Jambi lebih ditingkatkan lagi, baik dari segi proses produksi (Pengolahan lahan, penanaman, pemeliharaan dan panen) dan juga pemasaran untuk menambah atau meningkatkan jumlah produksi serta pendapatan petani kakao.

2. Dukungan dari Pemerintah kepada petani kakao ataupun bantuan berupa bibit agar masyarakat lebih terbantukan dalam pembudidayaan tanaman kakao.

3. Program Penyuluhan mengenai hama dan penyakit pada petani harus ditingkatkan, bahkan perlu didampingi dengan program lain agar dapat lebih meningkatkan kelembagaan petani kakao.

4. Kemitraan usaha antara industri/eksportir dengan petani/kelompok tani perlu ditumbuhkan dan ditingkatkan. Kemitraan usaha yang diharapkan adalah kemitraan yang profesional saling menguntungkan dan tidak terbatas dan hanya pemasaran hasil tetapi termasuk teknis budidaya dan peningkatan mutu.

5. Meningkatkan kualitas ekspor kakao dari kakao biji menjadi kakao bubuk atau produk olahan.

\section{DAFTAR PUSTAKA}

Anonimous, 2014. Monografi desa Betung Kecamatan Kumpeh Ilir Provinsi Jambi. Anonimous. 2009. Rencana Kegiatan Penyuluh Desa (RKPD). Badan Pelaksana Penyuluhan Pertanian Perikanan dan Kehutanan (BP4K). Desa Makmur Jaya, Kecamatan Betra, Kabupaten Tanjung Jabung Barat. 
Anggraini,A. 2016. Pendampingan koordinasi, bimbingan dan dukungan teknologi UPSUS Daging, TSP, TTP, dan Komoditas Utama Kementan, Laporan kegiatan RDHP tahun 2016.

Anonim, 2018. Programa Penyuluhan Pertanian Wilayah Kerja UPTD Jambi Selatan, 2019. Dinas Pertanian dan Ketahanan Pangan, Tanjung Jabung Barat.

Anwar, Affendi. 2006. Suatu Arah Tentang Analisis Institusi Sistem Kontrak Pertanian Wilayah Perdesaan. Suatu Petunjuk Bagi Keperluan Penelitian Bisnis Di Wilayah Perdesaan (Tidak Dipublikasikan). Program Studi Perencanaan Pembangunan Wilayah dan Perdesaan. Institut Pertanian Bogor, Bogor.

Arifin, Bustanul. 2003. Analisis Ekonomi Pertanian Indonesia. Kompas Media Nusantara. Jakarta.

Bambang Irawan, et al. 2005. Petunjuk Teknis PRA. Program Rintisan dan Akselerasi Pemasyarakatan Inovasi Teknologi Pertanian. Badan Litbang Pertanian. Departemen Pertanian.

Badan Litbang Pertanian. 2015. Pedoman Umum Pengembangan Taman Sains dan Teknologi Pertanian TSTP). Badan Litbang Peternakan, Kementerian Pertanian.

Badan Pusat Statistik. 2018. Badan Pusat Statistik Provinsi Jambi.

Budiharsono, Sugeng. 2001. Teknik Analisis Wilayah Pesisir dan Lautan (Cetakan Pertama). PT. Pradnya Paramita. Jakarta.

Dewan Kakao Indonesia, menyongsong pemberlakuan peraturan Menteri Pertanian, No.67/Permentan/OT.140/5/2014 tentang Persyaratan Mutu dan Pemasaran Biji Kakao, disampaikan pada Lokakarya, 27-28 Mei 2015, Suraqbaya.

Dinas Perkebunan Provinsi Jambi, 2015. Peluang Investasi Komoditas Utama Perkebunan. Invesment Opportunity of Estate Crops Main Communities.

Dinas Kehutanan dan Perkebunan Kabupaten Muaro Jambi, Manual Perbenihan menyongsong Komoditas Kakao, 2011.

Direktoran Jenderal Perkebunan, Petunjuk Teknis Budidaya Kakao Rakyaqt, 2012. Direktoran Jenderal Perkebunan, Kakao, 1995.

Direktorat Jenderal Perkebunan, Road Map Komoditi Kakao 2005-2025-2006

Pusat Penelitian Kopi dan Kakao Indonesia, Panduan Lengkap Budiday Kakao, 2004.

Dewanti,R dan G. Sihombing. 2012. Analisis Penapatan Usaha Peternakan Ayam Buras.

Djaenudin, D; Y. Sulaeman dan A. Abdurachman. 2002. Pendekatan Pewilayahan Komoditas Pertanian Menurut Pedo-Agroklimat di Kawasan Timur Indonesia. Jurnal Litbang Pertanian, 21:1.

inas Pertanian Provinsi Jambi. 2015. Sasaran Produksi Tanaman Pangan Tahun 2015 
E. Gumbira-Said, A. Harizt Intan. 2004. Manajemen Agribisnis. Penerbit Ghalia Indonesia. Jakarta.

Kusnadi U., Prasetyo L.H., Sinurat A.P., Hamid H., Masbulan E., Purba., Hasinah H., dan Priyanti A. 2001. Pengembangan Kelembagaan Bagi Stabilisasi Usaha ayam Ras Rakyat serta Fasilitas Kemitraan Yang Lestari. Laporan Penelitian. Badan Penelitian dan Pengembangan Pertanian. Pusat Penelitian Peternakan. Bogor.

Semiaji. 2011. Strategi Pembangunan Masyarakat Melalui PelibatanPartisipasi Masyarakat Dalam Pembangunan. Bunga Rampai Administrasi Publik. Lembaga Administrasi Negara. Jakarta.

Swastika DKS. 2004. Beberapa teknik analisis dalam penelitian dan pengkajian teknologi pertanian. Jurnal Pengkajian dan Pengembangan Teknologi Pertanian. Volume 7 Nomor 1 Puslitbang Sosial Ekonomi. Bogor.

Suharyon, Ani Susilawati, dan Erwan Wahyudi, 2016. Analisis Rekayasa Kelembagaan Penunjang Teknologi Usahatani Padi Lahan Sub Optimal Desa Karya Bakti Kecamatan Rantau Rasau Kabupaten Tanjung Jabung Timur Jambi. Proseding Seminar Nasional Inovasi Teknologi Pertania, 20 Juli 2016. Banjar Baru.

Soepadi. 2005. Pembangunan Pertanian dan Perekonomian Pedesaan Melalui Kemitraan Usaha Berwawasan Agribisnis. ICASERD Working Paper No. 60 .

Soekartawi, 2006. Analisis Usahatani. Penerbit UI Press Jakarta. 